Full-text Available Online at www.ajol.info and www.bioline.org.br/ia
J. Appl. Sci. Environ. Manage. Dec. 2016

Vol. 20 (4) 903-908

\title{
Extraction of a Low Grade Zinc Ore using Gravity and Froth Flotation Methods
}

\section{*11ALABI OLADUNNI OYELOLA; ${ }^{2}$ DALHATU ABOKI ABDU; ${ }^{3}$ ABERE DARE VICTOR ${ }^{4}$ IGONWELUNDU MAGNUS T; ${ }^{5}$ BALA MESHACK BOSAN; ${ }^{6}$ ARAOYE BABATUNDE OYEBODE}

\author{
'Metallurgical and Materials Engineering, Federal University of Technology, \\ P.M.B 704, Akure, Ondo State, Nigeria \\ ${ }^{2}$ Lead - Zinc Smelting Plant, National Metallurgical Development Centre, \\ P.M.B. 2116, Jos, Plateau State, Nigeria \\ ${ }^{1 *}$ Corresponding Author Email: oladunni69alabi@yahoo.com
}

\begin{abstract}
Extraction of low grade zinc ore found in Gumau- Toro town was carried out using gravity and froth flotation methods. Analysis of the chemical composition reveals that the crude ore contains $20.20 \%$ Zinc and other related minerals such as $66.72 \% \mathrm{SiO}_{2}, 2.36 \% . \mathrm{Pb}, 16.62 \% \mathrm{Fe}, 0.001 \% \mathrm{Ag}$, these are impurities that hindered the grade of zinc in this ore from appreciating. Fractional and grain sieve size results revealed that the liberation size of the ore is at $-355+250 \mu \mathrm{m}$ assaying $32.41 \% \mathrm{Zn}$. At this liberation sieve size, the low grade zinc ore was subjected to four different beneficiation methods using five kilograms $(5 \mathrm{~kg})$ each as charge into Wilfley shaking Table, Humphrey spiral concentrator, Air floating Machine and one kilogram $(1 \mathrm{~kg})$ for froth flotation. Resulting products (concentrate and tailing) from these processes were analyzed using instrumentation method. Percentage recovery of each applied process was calculated. This was used to ascertain that the use of froth flotation that gives $74.32 \% \mathrm{Zn}$ at a recovery of $84.62 \%$ stands out the best method for zinc extraction towards value addition to the low grade crude zinc ore. OJASEM
\end{abstract}

http://dx.doi.org/10.4314/jasem.v20i4.1

Key words: Extraction, Upgrading, Gravity, Froth flotation, Mineral, Fractional analysis.

The solid minerals industry is one of the strongholds that contribute to any nation's gross domestic product (GDP). A country like Nigeria can overcome its present economic struggle if attention is directed towards the solid mineral sector. This amongst other challenges has prompted the Federal Government of Nigeria (FGN) to generate interest and develop urgent policies on privatization of the solid mineral industry in order to reform the solid mineral subsector in diversification of the economy. Solid minerals of different varieties are largely available in Nigeria, this cuts across most locations around the country among is zinc ore found in Gumau-Toro area of Bauchi State.

Most zinc ores are chiefly beneficiated using flotation process; however, the use of gravity separation methods for separation of zinc from its ore has not been gainfully exhausted. Damisa (2007). Zinc ore deposits exist in Gumau-Toro area of Bauchi state in a commercially estimated reserve; record further shows that the deposit of this ore is of lower-grade. Craig and Vaughan (1981). In order to make it useful, then there is need for its extraction through beneficiation. Beneficiation is an important intermediate step in the transformation of natural ore to almost pure mineral. Craig and Vaughan, (1981). The concentration of the valuable minerals from the gangue involves exploitation of the differences in the minerals properties of the ore after effective commination. Adepoju and Olaleye, (2000).The success of this research work will boost the demand for the zinc metal, create wealth, generate employment and improve the nation's gross domestic product (GDP).

Zinc ore occurs in two types of deposit as primary ore in thin veins known as rakes or a secondary deposit formed by weathering of the primary veins. Zinc ore is most commonly found as zinc carbonate $\left(\mathrm{ZnCo}_{3}\right)$ known as Calamite or Smithsonite in US Doi Bereau of Mines (2016). It generally occurs as rounded crystallite crusts or granular honey combed masses that have a vitreous or pearly luster and are typically dirty brown or grey in colour. Locally it was known as 'dry bone' ore, having a cellular to spongy appearance reminiscent of dry bone. Ajayi, (2005). Froth flotation was used to concentrate Abakaliki Lead-Zinc sulphide ore deposit, and reported that it produced the best result and an improved concentrate. Gregory and Dume (1993). The oxidation and chloride leaching of sulphide concentrate was carried out in the past and was concluded that all chloride systems studied can be used to leach base metals from sulphide concentrated with metal extractions of greater than $80 \%$ being achieved at $90{ }^{\circ} \mathrm{C}$ with a retention time of $24 \mathrm{hrs}$ but complete dissolution cannot be obtained and chlorine cannot be used to extract nickel, copper or zinc preferentially from chalcopyrite or sphalerite. 
Gregory and Dume (1993). It was revealed that the major economic minerals present in Nahuta deposit are lead and zinc, and that flotation followed by differential flotation is best to achieve high recovery in the beneficiation of the ore. Damisa (2007).

In Froth Flotation processing method valuable mineral ore are liberated at fine particle size. Yaro (1997). Flotation agents or reagents are used. These are chemical substances that are added to the mineral pulp prior to or during flotation in order to make possible or facilitate the process. Gregory and Dume (1993). The flotation agents are known as collectors, depressants, frothier and modifiers. Damisa (2007). This process involves concentration finely ground ores that depends on the selective adhesion to air of specific minerals while the other remains submerged in the pulp. Gregory and Dume (1993). This is achieved by treatment with a suitable reagent (e.g. lime, oleic acid, propanol, turpentine etc.) of an ore pulp to create conditions favorable for attachment of certain hydrophobic or aerophilic mineral particles to bubbles and render the other solid hydrophilic submerged into the solution when air is applied Fuerstenan and Palmer (1976).

Gravity separation method is a processing method used to separate two or more minerals of different specific gravity by their relative movement in response to the force of gravity and one or more other factors (such as centrifugal force, magnetic, buoyant force) one of which is resistant to motion by a viscous medium such as heavy media water or less commonly air. This is controlled by factors such as weight, size and shape. All gravitational methods are common in the sense that they all use gravity as a dominant factor. Wills (2006). However, in gravity separation method, a heavy liquid analysis of the mineral which are liberated at coarse size will be carried out on the representative samples. Damisa (2007). Example of gravity separation methods are Air floatation, Spiral concentration, Jigging and wilfley methods.

The aim of this study is to upgrade a low grade zinc ore found in Gumau - Toro (Toro local government area, Bauchi state, Nigeria) to a higher grade zinc ore by way of value addition to about $65 \% \mathrm{Zn}$ as standard needed as a charge into the smelter for lead metal production, using gravity and froth flotation processing methods. And to determine the best separation technique (gravity and froth flotation) for upgrading this ore.

\section{MATERIALS AND METHODS}

Zinc ore used in this research was sourced from Gumau - Toro, in Toro Local Government Area, Bauchi State, Nigeria.

Sample Collection: $50 \mathrm{~kg}$ sample of low grade Zinc ore assaying 20.20\% Zn was collected from Gumau Toro, a town in Toro Local Government Area of Bauchi State, Nigeria; covering a land mass of about $503 \mathrm{~m}^{2}$ with co- ordinate Latitude $10.2478^{\circ} \mathrm{N}$, longitude $9.0178^{0} \mathrm{E}$ located between Rishi and Rimi Zayam village. This deposit has estimated reserve to be in a commercial quantity. This zinc ore sample was sourced from mining site with pit dug at an average dimension of 1.5 meters by 1.5 meters by 3 meters deep, using random sampling method.

Sample Preparation: Samples collected were in boulders form, with size ranging from $20 \mathrm{~cm}$ to $50 \mathrm{~cm}$ diameter. This was prepared by size reduced via crushing using Denver Jaw crusher, model BDA 15571 , type $A$, which reduces the size of the sample to about $5 \mathrm{~cm}$, with a further crushing in the Denver cone crusher, model and A003, Type 12, finally, size reduced in Deco roll crusher, model B7141A, to sieve size analysis range of below $2 \mathrm{~mm}$ in the mineral laboratory of the National Metallurgical Development Centre (NMDC), Jos. And was further size reduced to froth floatation size using Bico Sprecher Schuh laboratory ball milling machine, model 69012 (USA).

Chemical Composition of Crude Ore Sample: Chemical analysis of the ground Gumau-Toro low grade zinc ore sample was carried out by mixing the sample thoroughly until homogenized stage was achieved, followed by sampling using laboratory size riffles sampler. The resulting sample was then charged into analysis cup, pressed to a well compacted stage; this was then introduced for analysis using Pan Analytical Minipal-4, Energy Dispersive X-Ray Fluorescence Spectrometer (EDXRFS) analyzer of the Spectrum Mineral Laboratory, Industrial Estate, Rayfield Area Jos, and Plateau State.

Particle Size/Assay Analysis of Zinc Ore Sample: This is to establish the distribution of both the valuable and gangue minerals in the various size fractions leading to its Liberation size. Liberation studies establish the degree of freedom of the valuable minerals; which helps in the economic mesh of grind to be established. Wills (2006). The emphasis is placed on the grain size of valuable minerals and probably that of the gangue which may likely affect the separation process. $2 \mathrm{~kg}$ of zinc ore sample was collected from the $50 \mathrm{~kg}$ lot meant for the 
entire research work using cone and quartering sampling method; $100 \mathrm{~g}$ of this was charged into array of sieves placed on an Automated Endecott test sieve shaker with complete set of sieve, model EFL2mk11 (5471) ranging from $+1400 \mu \mathrm{m}$ to $-63 \mu \mathrm{m}$ using the root two $(\sqrt{2})$ formula. This machine was then operated for 30 minutes after which the contents of each sieve were discharged, weighed and recorded using Camry 25k5055 digital weighing balance.

Grain Size Analysis of Zinc Ore: Grain size analysis of Zinc ore was determined in the Mineralogy division of NMDC, Jos; by the use of Leco optical microscope. Sample was cut, molded by mounting the zinc ore sample using bakelite powder in a mounting press at setting temperature of $350^{\circ} \mathrm{C}$.Grinding and polishing of the sample prepared was done using various grits paper and was viewed on a calibrated microscope, with class interval of 100 .

Beneficiation Methods: Wilfley Shaking Tabling Method; $5.0 \mathrm{~kg}$ of the Gumau-Toro zinc ore crushed to required liberation size of $-355+250 \mu \mathrm{m}$ was charged into the laboratory size wilfley shaking table model 130 A of the Mineral Beneficiation Pilot Plant of NMDC, Jos after forming slurry mixed with water at ratio of 1:5 with deck tilted at $180^{\circ}$ at feed rate of 50 liters per hour, deck's speed set at 250 revolution per minute (RPM). Vissca (1976) and Alabi et al., (2006).

Spiral Concentrator Method: $5.0 \mathrm{~kg}$ of the prepared zinc ore sample was used at its liberation size of $355+250 \mu \mathrm{m}$. This was mixed with 25 liters of water to form slurry of ratio 1:5 with pulp density at 3.2 i.e. 25\%. Alabi et al. (2016) and Davis (1991). This was fed into the charging chamber of Humphrey Spiral Concentrator Model B124TA at a feed rate of 50 liters per hour and its valve set at $2 \mathrm{~cm}$ wide. The resulting products (concentrate and tailing) were collected in a 30 liters bucket, it was left over night (12 hrs.) to settle after which it was decanted, sun dried, weighed and sample picked for chemical composition analysis using ED-XRFS analysis machine.

Air floating Concentration Method: $5.0 \mathrm{~kg}$ of the ore at a sieve size of $-355+250 \mu \mathrm{m}$ was weighed and fed through the charging hopper to the deck of the Kip Kelly Air floating machine model My-1151, size 300 at a feed rate of $50 \mathrm{~kg}$ per hour with an inlet air opening at $2 \mathrm{~cm}$ at a deck slope of tilted at an angle of $180^{\circ}$. Taggart (1987) and Kimpel (1995) respectively. The resulting middling in bucket 3 and 4 were recycled, while the concentrate and tailing sample were weighed and taken for chemical compositional analysis using ED-XRFS analyzer.

Froth Floatation Method: $1.0 \mathrm{~kg}$ of prepared Gumau - Toro zinc ore sample of sieve size $-355+250 \mu \mathrm{m}$ was fed into Denver froth flotation cell, with $1000 \mathrm{mls}$ of water introduced, it was agitated for 5 minutes, the $\mathrm{pH}$ was tested and adjusted to 8 using Sodium Hydroxide (NaOH). Kimpel (1995) and Sinclair (2009), followed by the addition of Sodium Cyanide as depressant, 2 drops of sodium isopropyl xanthate $\left(\mathrm{Na}^{+}\left[\mathrm{CS}_{2}-\mathrm{O}-\mathrm{C}_{3} \mathrm{H}_{7}\right]\right)$. Bulavic (2013) and Yunana et al. (2015). Air was then introduced, froth was formed and bubbles of froth were skimmed out into the receiving container. These products were allowed to settle for 24 hours after which it was decanted, dried, weighed and sampled for chemical composition using ED-XRFS.

\section{RESULTS AND DISCUSSION}

The results obtained at the course of this research are as follows:

Table 1: Chemical Composition of Gumau-Toro Crude Zinc Ore

\begin{tabular}{llllll}
\hline Comp. (\%) & $\mathrm{SiO}_{2}$ & $\mathrm{Zn}$ & $\mathrm{Pb}$ & $\mathrm{Fe}$ & $\mathrm{Ag}$ \\
\hline Crude Lead-Zinc Ore & 66.72 & 20.20 & 2.36 & 16.62 & 0.001 \\
\hline
\end{tabular}

Table 2: Particle Size/Assay Analysis of Gumau-Toro Crude Zinc Ore

\begin{tabular}{llllll}
\hline $\begin{array}{l}\text { Sieve Sizes } \\
(\mu \mathrm{m})\end{array}$ & Weight $(\mathrm{g})$ & Weight $(\%)$ & $\begin{array}{l}\text { Cumulative } \\
\% \text { Retained }\end{array}$ & $\begin{array}{l}\text { Cumulative } \\
\text { \% passing }\end{array}$ & $\% \mathrm{Zn}$ \\
\hline+1400 & 7.20 & 7.24 & 7.40 & 92.76 & 18.70 \\
$-1400+710$ & 6.12 & 6.17 & 13.41 & 86.59 & 21.80 \\
$-710+500$ & 9.21 & 9.26 & 22.67 & 77.33 & 21.20 \\
$-500+355$ & 10.16 & 10.22 & 32.89 & 67.11 & 32.41 \\
$-355+250$ & 12.64 & 12.72 & 45.61 & 54.39 & 24.81 \\
$-250+180$ & 12.12 & 12.19 & 57.80 & 42.20 & 23.60 \\
$-180+125$ & 14.03 & 14.11 & 71.91 & 28.09 & 22.80 \\
$-125+90$ & 13.42 & 13.51 & 85.4 & 14.58 & 22.70 \\
$-90+63$ & 12.16 & 12.23 & 97.65 & 2.35 & \\
-63 & 2.34 & 2.35 & 100.0 & - & \\
\hline
\end{tabular}




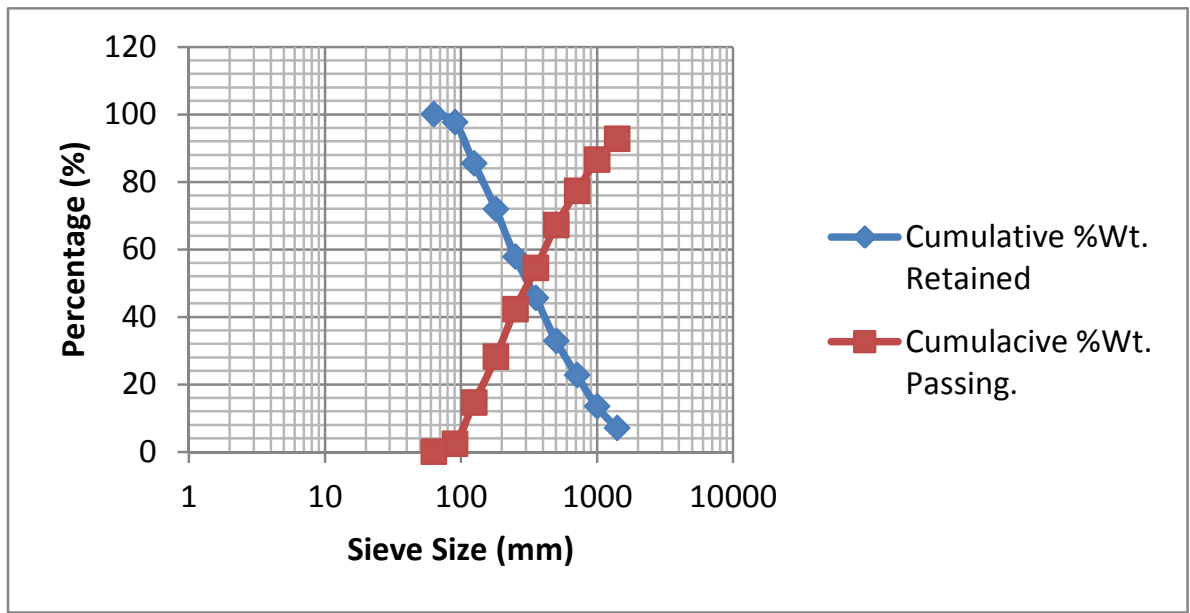

Fig 1: Presents the Log- Log Plot of Cumulative \%Wt. Retained and Cumulative \%Wt. Passing against the sieve sizes

Table 3: Grain Sieve Size Analysis of Gumau -Toro Zinc

\begin{tabular}{llll}
\multicolumn{3}{c}{ Ore } \\
\hline Class Intervals & Mid - Point & Frequency & FX \\
& X & F & \\
\hline $001-100$ & 50.5 & 40.0 & 2020 \\
$101-200$ & 150.5 & 390.0 & 58695 \\
$201-300$ & 250.5 & 556.0 & 139278 \\
$301-400$ & 350.5 & 245.0 & 85872.5 \\
$401-500$ & 450.5 & 95.0 & 42797.5 \\
$501-600$ & 550.5 & 53.0 & 29176.5 \\
$601-700$ & 650.5 & 36 & 2341.8 \\
$701-800$ & 750.5 & 41 & 30770.5 \\
$801-900$ & 850.5 & 29 & 24664.5 \\
$901-1000$ & 950.5 & 16 & 15208.0 \\
& & $\Sigma F=15,000$ & $\Sigma F X=430824.3$ \\
\hline
\end{tabular}

Table 4: Chemical Composition of processed Zinc ore using Wilfley, Spiral, Air floatation and Froth Flotation Methods.

\begin{tabular}{lllllll}
\hline Composition $(\%)$ & & $\mathrm{SiO}_{2}$ & $\mathrm{Zn}$ & $\mathrm{Pb}$ & $\mathrm{Fe}$ & $\mathrm{Ag}$ \\
\hline Wilfley & Conc. & 20.21 & 72.44 & 3.75 & 1.77 & 0.04 \\
& Tailing & 63.62 & 10.62 & 12.02 & 11.14 & 0.001 \\
Spiral & Conc. & 52.70 & 42.44 & 2.23 & 1.59 & 0.04 \\
\multirow{4}{*}{ Air floating } & Tailing & 56.39 & 25.35 & 6.19 & 10.06 & 0.005 \\
\multirow{3}{*}{ Froth Floatation } & Conc. & 25.92 & 64.03 & 5.67 & 1.36 & 0.04 \\
& Tailing & 61.23 & 18.13 & 7.16 & 12.19 & 0.001 \\
& Conc. & 18.79 & 74.32 & 3.05 & 1.23 & 0.03 \\
& Tailing & 68.32 & 12.43 & 8.02 & 10.84 & 0.001 \\
\hline
\end{tabular}

Table 5: Recovery of Zinc from Zinc ore

\begin{tabular}{llllll}
\hline \multirow{2}{*}{ Wilfley } & Wt. Of Charge & $\begin{array}{l}\text { Weight of } \\
\text { Product }(\mathrm{kg})\end{array}$ & \% Zinc & $\begin{array}{l}\text { Recovery } \\
(\%)\end{array}$ \\
& Conc. & 5.0 & 1.09 & 72.44 & 78.18 \\
\multirow{2}{*}{ Spiral } & Tailing & & 3.71 & 10.62 & 41.01 \\
& Conc. & 5.0 & 1.82 & 42.44 & 76.48 \\
\multirow{3}{*}{ Airfloatig } & Tailing & & 3.17 & 23.35 & 73.29 \\
& Conc. & \multirow{2}{*}{5.0} & 1.23 & 63.03 & 76.76 \\
& Tailing & & 3.76 & 18.13 & 67.49 \\
Froth & Conc. & \multirow{2}{*}{1.0} & 0.23 & 74.32 & 84.62 \\
\hline
\end{tabular}

From the results presented, Table 1 shows the chemical composition of the crude zinc sample with 20.20\%zinc, $66.72 \% \mathrm{SiO}_{2}, 2.36 \%$ Lead, $16.62 \%$ Iron and $0.001 \%$ Silver. The mineral of interest, zinc 
assays $20.20 \%$ by composition this met the typical standard of 1-10\% $\mathrm{Zn}$ which a mineral must possess to qualify the mine as viable for exploration towards a particular mineral concentration. Wills (2006). While the fractional sieve size analysis of GumauToro Crude Zinc ore as presented in Table 2 shows that at sieve size of $-355+250 \mu \mathrm{m}$, the cumulative weight $\%$ retained and cumulative weight $\%$ passing are 45.61 and 54.39 respectively; hence giving an assay $32.41 \% \mathrm{Zn}$. At sieve of +1400 the cumulative weight $\%$ retained and cumulative weight $\%$ passing are 7.40 and 92.76 respectively with an assay of $18.70 \% \mathrm{Zn}$ being the least assay of the entire sieve grades. All other sieve sizes present assay Zinc of between 21.0 to $24.81 \% \mathrm{Zn}$, this further confirmed that $-355+250 \mu \mathrm{m}$ sieve size is the optimum liberation size for the beneficiation of the crude low zinc ore. Wet and Singleton (2008) and Yunana et al (2015). Fig. 1; shows the plot of the percentage (\%) cumulative weight retained and \% cumulative weight passing of the ore against its sieve sizes. It can be observed that at about $300 \mu \mathrm{m}$ sieves size there is an intersection between the curves thus could be considered to be the optimum liberation sieve size for the mineral under study.

From Table 3, grain crystal of Zinc ore was measured using Standard deviation to be $0.287 \mathrm{~mm}$, which is scientifically $0.287 \mathrm{~mm}(287 \mu \mathrm{m})$. the grain size of the Zinc ore sample at varying shapes, colors, measured in class interval of 100. Finally, class interval and frequency were used to calculate the standard deviation which gave the required grain size of the Zinc ore to be $287.2 \mu \mathrm{m}$ (Appx. 300 $\mu \mathrm{m}$ ) and invariably its liberation size as revealed in

Table 3. i.e. $\mathrm{X}=\frac{\Sigma F X}{\Sigma F}=\frac{430824.3}{1500}=287.2 \mu \mathrm{m}$

$=($ Appr. 300 $\mu \mathrm{m})$

Furthermore, the resulting products of various processes were weighed, sampled and analyzed for chemical composition; the results are as shown in Table 4. From the result in this table it was observed that the Wilfley shaking table has an assay of 72.44 $\% \mathrm{Zn}$ for the concentrate and $10.62 \% \mathrm{Zn}$ tailings with recoveries of 78.18 and 41.01 respectively; with $20.21 \% \mathrm{SiO}_{2}$ in concentrate and $63.62 \% \mathrm{SiO}_{2}$ in tailings; this shows an improvement in the percentage assay of the zinc ore present in this mineral. Table 4 shows that using the spiral concentration method the resulting product has an assay of $42.44 \% \mathrm{Zn}$ as concentrate and the tailing assaying $23.35 \% \mathrm{Zn}$ at the recoveries of 76.48 and 73.29 respectively. This result shows slight improvement in assay of concentrate zinc ore though it failed to meet up with the required charging assay of $65 \% \mathrm{Zn}$ and so refers to as not effective for the upgrading of this ore. While Table 4 and Table 5 shows the result of this chemical analysis of both the concentrate and tailing produced using air floating method. Concentrate assays 63.03 $\% \mathrm{Zn}$ and tailing assays $18.13 \% \mathrm{Zn}$ with recoveries of $76.76 \%$ and $67.49 \%$ respectively. This shows that the use of air float though improved the concentrate value and grade but failed to meet the $65 \% \mathrm{Zn}$ standard required as a charge towards zinc smelting. Wet and singleton (2008) and Billi and Quai (1963). Finally, froth flotation method produced result with an assay shown in Tables 4 and 5 of $74.32 \% \mathrm{Zn}$ for the concentrate and $12.43 \% \mathrm{Zn}$ tailings with recoveries of 84.62 and 46.16 respectively. This shows that this processing method met the required charging assay standard of $65 \% \mathrm{Zn}$ for blast furnace production. Billi and Quai (1963) and Fourie et al., (2006), and could be recommended as effective for this value addition.

Conclusion and Recommendation: The ore was confirmed to be low grade zinc ore which was upgraded using both gravity and froth flotation techniques (methods). Wilfley shaking tabling and froth flotation techniques gave $s$ higher grade and recovery, while spiral concentration and air flotation techniques gave lower values. However, only froth flotation technique produced concentrate that met the standard requirement of $65 \% \mathrm{Zn}$ needed as a charge in zinc smelter. And thus proved to be the best and preferred beneficiation technique for processing of Gumau - Toro zinc ore and it is hereby recommended.

Acknowledgement: The authors would like to appreciate the Management of National Metallurgical Development Centre (NMDC) Jos, SINO Star Minerals Laboratory, Mai Adiko and Spectrum Minerals Industries, Jos; for allowing us the use of their mineral laboratories for our bench work and the analytical laboratories for chemical analysis. Finally, the technical staff and all members of staff of these establishments that contributed in one way or the other towards making this research a success, are also appreciated.

\section{REFERENCES}

Adepoju, S. O; and Olaleye, B.M. (2000). Gravity Concentration of Silica Sand from Itakpe IronOre Tailings by Tabling Operation. NJE Management. 2 (1): 51-52.

Ajayi, J.A; (2005) Froth Flotation Recovery of Galena Concentrate from Abakaliki Sulfide Ore Deposit, South Eastern Nigeria. Journal of Mining and Geology. 1 (1): 41-46. 
Alabi, O.O; Yaro, S.A; Dungka, G.T; Asuke, F. and Hassan, B. (2016). Comparative Beneficiation Study of Gyel Columbite ore using Double Stage (Magnetic-Magnetic and Magnetic-Gravity) Separation Techniques. Journal of Minerals Characterization and Engineering. 4 (1): 181 193.

Billi, M. and Quai, V. (1963). Development and Results Obtained In the Treatment of Zinc Oxide Ores at The AMMI Mines. VI International Mineral Processing Congress, Cannes. 1(1): 631649.

Bulatovic Srdjan, M. (2013). Hand book of Froth Flotation Reagents. Chemistry Theory and Practice, Elsevier Copyright. 3 (1): 123-137.

Craig, J. R; Vaughan D.J (1981). Ore Microscopy and Ore Petrography. John Wiley and Sons, New York. 1(1): 025 - 026.

Damisa, E. O (2007). Process Design for the Beneficiation of Nahuta Lead Deposit Bauchi State. Ph.d Dissertation, Department of Metallurgical Engineering. A.B.U., Zaria. Unpublished. 23- 47. Http://Www.Spectrumsorter.Com

Davis, E.M (1991). Beneficiation of Eastern Masabi Magnetic Material. University of Minnesota Mines Experimental station information. 5(1): 4 - 6 .

Fourie, H; Van, P.H; Rupprecht, S; Lund, T; Vegter, N.M (2006). Exploitation of A Massive Low Grade Zinc-Lead Resource At Rosh Pinah Zinc Corporation. SAIMM Conference, Africa's Base Metal Resurgence, Swakopmund, Namibia. 2327.

Fuerstenau, M.C; Palmer B.R (1976). Anionic Flotation of Oxides and Silicates. Edited by M.C Fuerstenau, New York: AIME. 1(1): 17 -22.

Gregory, S.; Dume R (1993). Chloride Leaching of Gold from Sulphide Concentrate. International Symposium on the treatment of Gold ores, Newton Australia Ltd. 2 (4): 12-17.
Klimpel, R.R (1995). The Influence of Frothier Structure on Industrial Coal Flotation. High Efficiency Coal Preparation (Kawatra, ed.), Society for Mining, and Metallurgy. 1(1): 12-16.

Sinclair, R.J (2009). The Extractive Metallurgy of Lead. Australasian Institute of Mining and Metallurgy. 15(1): 8-21.

Taggart, A.F (1987). Hand Book of Mineral Dressing, New York Sec II, Ref 8. John Willey and Sons.11-55.

US. DOI.Bereau of Mines. (2016) Extraction and Beneficiation of Ores and Minerals, Lead-Zinc. Washington D.C. United State Environmental Protection Agency. 1(2): 5-13.

Vissca, G (1976). Coal Preparation with the Modern Feldspar Jig. Trans. AIME. 202 (1): 649 - 655.

Wet De, K; Singleton, J.D (2008) Development of a Viable Process for the Recovery of Zinc from Oxide Ores. The Southern African Institute of Mining and Metallurgy, Proceedings of LEAD and ZINC, Durban. 177-192

Wills, B.A.M (2006). Mineral Processing Technology. New York: Elsevier Science and Technology Books. 75- 83.

Yaro, S.A (1997). Development of A Process Route for the Beneficiation of Mallam Ayuba Manganese Deposit to Ferromanganese Feed Grade. Ph.D Dissertation, Ahmadu Bello University, Zaria, Metallurgical Engineering Department. 1- 45 .

Yunana, M.B; Yaro S.A; Thomas D.G (2015) Characterization of Zurak lead-zinc ore using XRay Florescence (XRF) Spectrometry and X-Ray Diffraction (XRD). Nigeria Journal of Engineering, 22 (1): O9 - 014. 